\title{
Modeling the cost of eradicating livestock-associated methicillin-resistant staphylococcus aureus in countries with a high proportion of positive herds
}

Olsen, J.V.; Calvo Artavia, F. F.; Sandøe, P.; Toft, N.

Published in:

Preventive Veterinary Medicine

Link to article, DOI:

10.1016/j.prevetmed.2018.07.010

Publication date:

2018

Document Version

Peer reviewed version

Link back to DTU Orbit

Citation (APA):

Olsen, J. V., Calvo Artavia, F. F., Sandøe, P., \& Toft, N. (2018). Modeling the cost of eradicating livestockassociated methicillin-resistant staphylococcus aureus in countries with a high proportion of positive herds. Preventive Veterinary Medicine, 158, 97-105. https://doi.org/10.1016/j.prevetmed.2018.07.010

\section{General rights}

Copyright and moral rights for the publications made accessible in the public portal are retained by the authors and/or other copyright owners and it is a condition of accessing publications that users recognise and abide by the legal requirements associated with these rights.

- Users may download and print one copy of any publication from the public portal for the purpose of private study or research.

- You may not further distribute the material or use it for any profit-making activity or commercial gain

- You may freely distribute the URL identifying the publication in the public portal 
Københavns Universitet

Modeling the cost of eradicating livestock-associated methicillin-resistant staphylococcus aureus in countries with a high proportion of positive herds

Olsen, Jakob Vesterlund; Calvo-Artavia, Francisco Fernando; Sandøe, Peter; Toft, Nils

Published in:

Preventive Veterinary Medicine

DOI:

10.1016/j.prevetmed.2018.07.010

Publication date:

2018

Document version

Peer reviewed version

Document license:

CC BY-NC-ND

Citation for published version (APA):

Olsen, J. V., Calvo-Artavia, F. F., Sandøe, P., \& Toft, N. (2018). Modeling the cost of eradicating livestockassociated methicillin-resistant staphylococcus aureus in countries with a high proportion of positive herds. Preventive Veterinary Medicine, 158, 97-105. https://doi.org/10.1016/j.prevetmed.2018.07.010 


\title{
Modeling the cost of eradicating livestock-associated methicillin- resistant staphylococcus aureus in countries with a high proportion of positive herds ${ }^{1}$
}

\author{
J. V. Olsen ${ }^{a^{*}}$, F.F. Calvo-Artavia ${ }^{b}$, P. Sandøe ${ }^{a c}$, N. Toft ${ }^{b}$ \\ ${ }^{a}$ Department of Food and Resource Economics, University of Copenhagen, Denmark \\ ${ }^{\mathrm{b}}$ Division for Diagnostics \& Scientific Advice, National Veterinary Institute, Technical \\ University of Denmark \\ ${ }^{\mathrm{c}}$ Department of Veterinary and Animal Sciences, University of Copenhagen, Denmark \\ *Corresponding author: \\ E-mail: jvo@,ifro.ku.dk \\ Postal address: Rolighedsvej 25, DK 1958 Frederiksberg C.
}

Phone: +4535333588

\begin{abstract}
Due to an increased incidence of human infections, livestock-associated methicillin-resistant Staphylococcus Aureus (LA-MRSA) in pigs and its spread into the human population has been a major public and political issue in Denmark. Similar concerns are also being raised about LAMRSA in other Western European countries. At a time when the proportion of LA-MRSApositive pig farms was low, Norway adopted a 'trace and destroy' strategy aimed at keeping LA-MRSA out of the pig population. However, to date, no country with a high proportion of LA-MRSA-positive pig herds has chosen to use an eradication strategy. This study analyses the cost and complexities of conducting an LA-MRSA eradication program in a situation where a large proportion of herds are positive. The total cost of the eradication program was estimated based on the following components: 1) planning, 2) monitoring and testing, 3) cleaning and disinfection, 4) production gains and losses, 5) net reduction in breeding exports, and 6) loss of genetic progress, including the costs of a mitigating caesarean section strategy in breeding herds. Costs were related to the depopulation of 1 million sows, to gilt supply (as this was an important limiting factor during an eradication program in Denmark), and to aggregated losses linked to a temporary halt on breeding progress. Using conservative assumptions, the total eradication costs were estimated at $€ 1.8$ billion, broken down into:

\footnotetext{
${ }^{1}$ The reference of the printed version is:

Olsen, J. V., Calvo-Artavia, F. F., Sandøe, P., \& Toft, N. (2018). Modeling the cost of eradicating livestockassociated methicillin-resistant staphylococcus aureus in countries with a high proportion of positive herds. Preventive Veterinary Medicine 158: 97-105.
}

The definitive version is available at https://doi.org/10.1016/j.prevetmed.2018.07.010 
planning costs $(3 \%)$, monitoring and testing (6\%), cleaning and disinfection (19\%), production gains and losses (33\%), net loss from breeding exports (19\%) and loss of genetic progress $(20 \%)$. The long-term effects of an LA-MRSA eradication program for Danish pig production were uncertain and were therefore not taken into account in the analysis.

Keywords: LA-MRSA, CC398, Eradication, Cost Analysis

\section{Introduction}

The livestock-associated methicillin-resistant Staphylococcus aureus (LA-MRSA) clonal complex (CC) 398 has been reported in pig populations and humans in contact with pigs, especially farm workers (Voss et al., 2005; Armand-Lefevre et al., 2005), since 2004. The occurrence of LA-MRSA in Danish pig herds increased rapidly from 3\% positive farms in 2008 to $88 \%$ positive farms in 2016 (Danish Veterinary and Food Administration, 2017). The pig population in Denmark therefore constitutes a major reservoir of LA-MRSA CC-398. In addition, there was an annual increase in the incidence of LA-MRSA CC398 infections within the Danish human population of 66\% per year between 2004 and 2011 (Larsen et al., 2015). This, together with a fierce public debate among experts and stakeholders, amplified by media exposure, has prompted Danish politicians to consider control measures for LA-MRSA in Danish pig herds, as well as initiatives to prevent further spread to humans.

In Norway, a country with an initially very low proportion of positive farms, a "trace and destroy" strategy has been implemented, through which farms delivering or receiving pigs from positive farms are tested. LA-MRSA-positive farms are depopulated without bringing pigs to slaughter, followed by re-stocking with uninfected animals after cleaning and disinfection of the premises. This strategy has a reported $90 \%$ probability of successfully eradicating LAMRSA on a positive Norwegian farm (Grøntvedt et al., 2016). It has been suggested by several influential stakeholders that the best option to control LA-MRSA in Danish pig herds would be to follow the Norwegian example and depopulate LA-MRSA-positive pig herds. Indeed, part of the political mandate of an expert group reconvened by the Danish Minister for the Environment, Food and Agriculture in 2016 was to consider this option. However, when the proportion of positive herds is as high as in Denmark, bottleneck issues and production constraints (e.g. the availability of replacement animals) adds to the complexity of the problem. When considering the costs and benefits of eradicating LA-MRSA from the Danish pig herd, it is important to realise that direct benefits are almost exclusively achieved outside the pig sector, i.e. in the public health sector. While it is important to consider these benefits when deciding whether or not to initiate an eradication program within a country, they are not relevant when trying to calculate the associated costs. Furthermore, societal costs associated with losses in slaughterhouses, feed mills and various other services for the primary pig industry are most likely to be directly related to a reduction in the number of pigs produced during eradication, and will depend on the structure of the pig industry in the country. Hence, societal costs are not considered further in this study. The costs incurred in the primary production sector, 
however, can probably be extrapolated from the Danish situation to any industrialised pig production sector with a high proportion of LA-MRSA-positive farms.

There may also be some indirect benefits of an LA-MRSA eradication program. For example, it may be possible to include the benefits of eradicating one or more further diseases such as Porcine Reproductive and Respiratory Syndrome (PRRS), Actinobacillus pleuropneumoniae and Enzootic Pneumonia into the cost analysis.

The purpose of this study was to analyse the cost and complexities of conducting an eradication program for LA-MRSA-positive herds in Denmark - a country with a high proportion of positive herds to assess the production losses using similar methods as in previous studies (Houe, 2003; Rushton, 2009; Asheim et al., 2017; Thomann et al., 2017). The main challenge for our analysis is the uncertainty about the underlying assumptions, for example regarding reintroduction rate. To address this uncertainty, we use a conservative approach by which assumptions are chosen so that the combined costs reflect an optimistic estimate of the total cost, and by subsequently performing a sensitivity analysis comparing this estimate to the worst-case scenarios.

\section{Materials and methods}

\section{Analytical approach}

The proposed eradication strategy consisted of: an initial one-year planning phase, a five-year eradication phase and a nine-year monitoring and control phase, during which LA-MRSApositive farms were depopulated and restocked. In total, a timescale of 15 years was considered.

The cost of an LA-MRSA eradication program for the primary pig sector in Denmark was calculated as the net present value (NPV) of the costs and losses of the program (Eq. (1)). The cost analysis was divided into costs during the planning period, direct net costs during the eradication period, and derived net costs after the eradication period. The calculation was similar to that of Asheim (2017):

$$
N P V=\sum_{i=1}^{n} \frac{- \text { CostProg }_{i}-\text { LossProg }_{i}}{(1+r)^{i}}
$$

Where $i$ is the year (with 2018 considered as the start of the eradication program); $n$ is the timescale of the program (15 years); $r$ is the real interest rate (4\%). The CostProg is the cost of the planning, testing and monitoring, cleaning, disinfection and caesarean section in year $i$ (Fig. 1). LossProg includes production losses, the losses from a reduced export of genetics, and losses from reduced breeding progress in year $i$. The expected benefits related to an 
improvement in the health status of the pigs were subtracted from the losses. A static approach was adopted without assuming long-term effects on the farm or production structure.

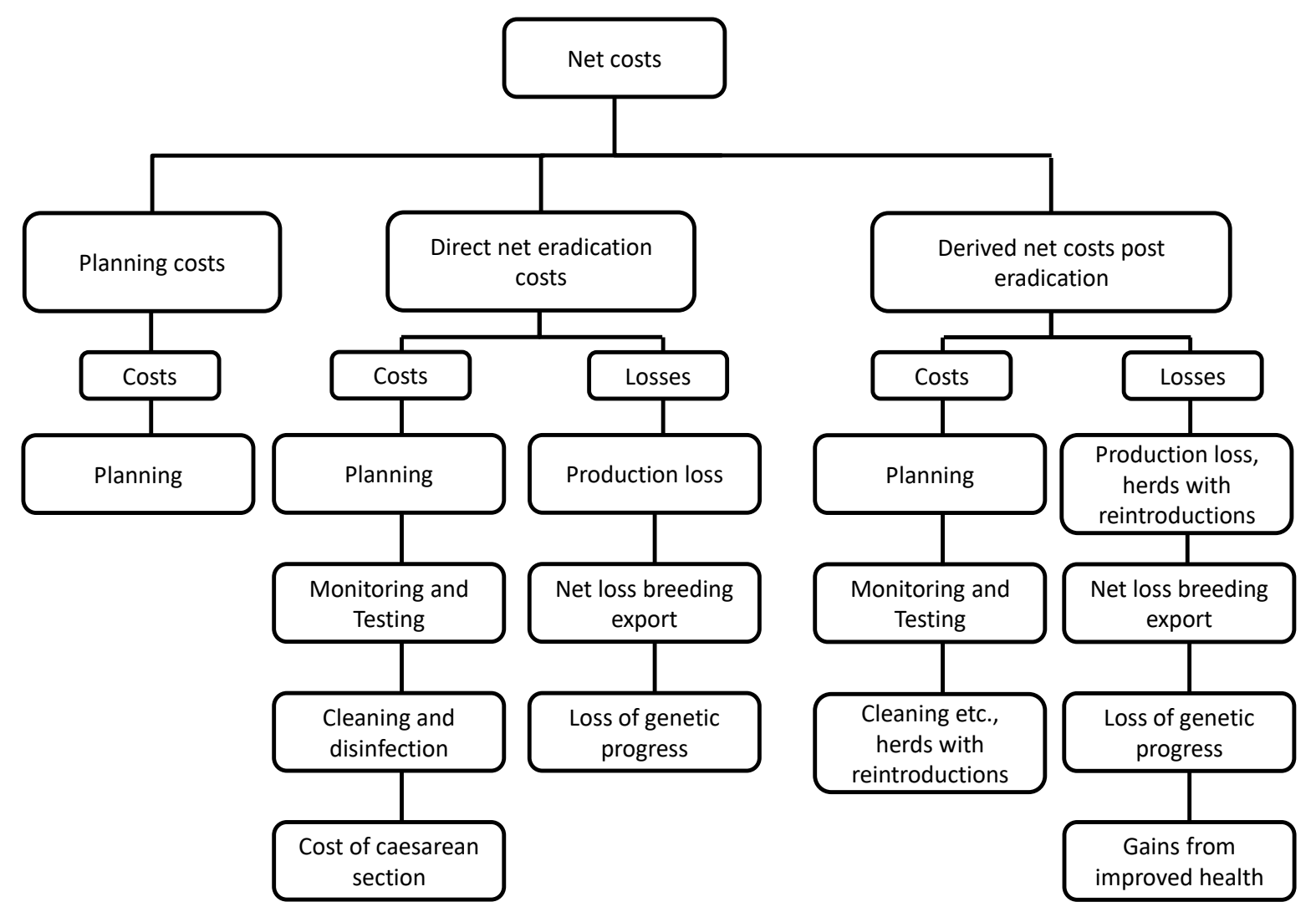

Figure 1. MODEL STRUCTURE FOR THE BREAKDOWN OF COSTS. DiRECT NET COSTS COVER PLANNING AND ERADICATION PHASES AND DERIVED NET COSTS COVER THE MONITORING PHASE FOLLOWING THE ERADICATION OF LA-MRSA IN DENMARK.

The sensitivity was calculated using a static ceteris paribus analysis based on an assessment of relevant assumptions. The costs and losses were recalculated with one of the assumptions changed, and the difference compared to the baseline was calculated. If several assumptions were mutually dependent, the cumulative effect was calculated by changing these assumptions simultaneously and subtracting the baseline costs.

\section{Planning and initial screening}

It was assumed that 200 hours of planning were required per LA-MRSA-positive farm throughout the eradication and restocking phases based on previous Danish experience from the unsuccessful eradication attempts concerning Salmonella Typhimurium DT 104. The initial planning phase was set to one year, including an initial screening of all herds in Denmark to establish the LA-MRSA status of the farms. The planning phase would involve public authorities, veterinarians, consultants and farmers. 


\section{Testing and monitoring}

We assumed that all herds were tested during the planning phase (year one) to establish the true LA-MRSA status of all farms. During years two and three, one-third of the farms would each be tested four times per year. During years three and four, two-thirds of the farms would each be tested four times per year, and in the fifth year, all farms would be tested once to ensure that the eradication program had been successful. During years six to 15, all herds would be tested annually to confirm their continued negative status. Simulation studies have been conducted showing that frequent testing is necessary to keep the transmission rate between herds low. Each herd was tested with 5 pooled tests per herd at an expected cost of $€ 934$ per herd.

\section{Production gains and losses}

Production loss was calculated according to the following equation (Eq. (2)):

Production loss $=\sum_{j=1}^{2} \sum_{k=1}^{3}$ production $_{j k} \cdot$ fraction of year ${ }_{j k} \cdot{\text { annual gross } \text { margin }_{k}}$

Where production was the total number of pigs from farms with LA-MRSA; fraction of year was the period with no pigs delivered from the farm; annual gross margin was the national average (see Appendix 1 for detailed description); $j$ was the type of production (integrated $=1$, specialised farms $=2$ ), and $k$ was the age group of the pigs (piglets $=1$, weaners $=2$, finishers $=$ $3)$.

In farm accounts, not all variable costs are deducted from the revenue to obtain the gross margin (Huirne \& Dijkhuizen, 1997). Nonetheless, gross margins are often used to approximate the losses during ceased production (Thomann et al., 2017). However, energy and labour costs are usually also affected by the eradication program because the number of pigs is lower during the eradication and restocking phase. The expected losses from the eradication program were therefore calculated as the gross margin adjusted with $50 \%$ of the energy and $10 \%$ of labour costs during the depopulation and restocking period. Labour costs were not expected to decrease further due to additional cleaning tasks and logistic constraints on the workforce to avoid reintroduction of LA-MRSA through human contact.

The eradication program evaluated in this study allowed for slaughter pigs to be reared to commercial weight and for piglets to be sold at a commercial price. However, a loss was expected due to productive sows being slaughtered prematurely. This loss was calculated using the costs associated with rearing gilts to about 35 weeks and buying $10 \%$ extra gilts, since they would not all be expected to be useful for production. 


\section{Cleaning and disinfection}

Cleaning and disinfection in relation to LA-MRSA was expected to be costly since the bacteria can survive in the environment. The scope of eradication was considered to be comparable to a Salmonella typhimurium DT104 eradication program, conducted (unsuccessfully) in Denmark in the late 1990s. The unpublished costs from this eradication program were divided into: destruction of feedstuffs (22\%), cleaning and disinfection of pens (40\%), cleaning of machinery and outdoor premises (14\%) and reduction in slurry value (24\%; Danish Pig Research Centre, unpublished).

\section{Loss of genetic progress}

Breeding is basically taking advantage of the variation in the genes within a species to choose the best performing individuals (Rauw, 2008). The traits selected in pig breeding maximise the economic return from pig farming (Pig Research Centre, 2014). An eradication program involving culling of breeding stock reduces the number of available pigs and - as a consequence - variation in the genes. This implies a reduction in the genetic progress for nucleus herds during the eradication program. After the eradication program, genetic progress would return to its previous growth rate. However, a perpetual disparity would remain between the breeding value with and the value without (baseline) an eradication program.

The genetic progress in Danavl (cooperatively owned Danish breeding company) was estimated at $€ 1.70$ per pig per year (from birth to slaughter) as an average over four years and based on the progress of nine parameters (Pig Research Centre, 2014, 2016). These parameters were: growth rate, feed conversion ratio, leanness, living piglets at day five, conformation, killing out percentage, piglet growth, longevity, and paternal fertility (Pig Research Centre, 2016). This average of $€ 1.70$ per pig reared from birth to slaughter was used to estimate the loss of breeding progress. About half of this genetic progress value was expected to be lost due to the depopulation of $86 \%$ of breeding pigs in the nucleus herds. This loss of genetic development was estimated assuming unchanged breeding value estimates for precision, variation in genetic material, and generational interval. For simplicity, these parameters are assumed to be independent of the eradication program. The equation used for genetic progress per year (Eq. (3)) was as follows (Jespersen 2008):

$$
\Delta G_{y e a r}=\frac{i \boldsymbol{r}_{A I} \sigma_{A}}{L}
$$

Where $(i)$ is the selection intensity, $\left(r_{A I}\right)$ is the precision of the breeding value estimates (i.e. the number of tests), $(\sigma)$ is the variation in genetic material, and $(L)$ is the generational interval. The genetic progress for offspring is the average of the maternal and paternal contributions which are both calculated according to eq. 3. The probability of a positive LA-MRSA breeding herd was assumed to be independent of the breed and the herd size. Simplified assumptions of unchanged breeding value estimates for precision, variation in genetic material and generational interval were also made, so that the breeding progress was only dependent on the 
selection intensity before and during the eradication program. The ex post selection intensity was based on there being 280 LA-MRSA-negative sows in each of the three breeds used in Danish pig breeding, each producing annually 2,800 useful gilts. See Appendix 2 for a calculation of the economic loss incurred due to loss of breeding progress.

\section{Caesarean sections}

It was assumed that the breeding progress loss could, in principle, be mitigated by caesarean sections in combination with artificial fostering of piglets, thus allowing LA-MRSA-negative piglets to be raised from positive sows. An eradication program using caesarean sections would be logistically challenging and involve high operating costs including those associated with transportation, caesarean clinics, veterinarians, and high gilt mortality. The number of caesareans was assumed to be sufficient to produce the necessary 4,600 high quality nucleus gilts the first year and an equal number of boars. See Appendix 2 for an approximation of costs related to caesarean sections used to maintain breeding progress.

\section{Loss of export value for gilts, boars and semen}

The eradication program was expected to reduce the export of gilts, boars and semen from breeding herds, resulting in a loss of revenue during the program. The effect on Danish companies of the delay in genetic progress during the eradication program (compared to companies doing their breeding outside Denmark) might mean that a full recovery of preprogram markets is doubtful. However, due to our conservative approach in estimating costs, we assumed that we would regain full market access. A calculation of the loss of export value is presented in Appendix 3.

\section{Demographics of Danish pig production}

In 2016, 227 Danish pig herds were tested for LA-MRSA, resulting in an estimated proportion of $88 \%$ LA-MRSA-positive slaughter pig herds in Denmark (Danish Veterinary and Food Administration, 2017). Assuming a similar relationship exists to that found during a study conducted in 2014 (DANMAP, 2015) of 63\% positive breeding herds and 68\% positive slaughter pig herds, we assumed that the proportion of LA-MRSA-positive breeding herds was $86 \%$.

In 2017, Danish pig production consisted of a yearly production of approximately 18 million slaughter pigs and 13 million weaner pigs for live export, from about 1 million sows. Table 1 shows the estimated number of LA-MRSA-positive herds, categorised by type (Ministry of Environment and Food of Denmark, 2017). This was based on the assumption of $88 \%$ positive herds, and the distribution across different herd types is shown. 
TABLE 1. ESTIMATED NUMBER OF LA-MRSA-POSITIVE DANISH PIG HERDS AND DISTRIBUTION OF PIGS (\%) BY HERD TYPE, FROM THE HERD STATISTICS IN DENMARK

\begin{tabular}{lllll}
\hline Herd type & $\begin{array}{l}\text { Estimated number } \\
\text { of LA-MRSA- }\end{array}$ & $\begin{array}{l}\text { Sows } \\
(\%)\end{array}$ & $\begin{array}{l}\text { Weaners } \\
(\%)\end{array}$ & $\begin{array}{l}\text { Finishers } \\
\text { positive herds }\end{array}$ \\
& 500 & 12 & - & - \\
\hline Specialised sow herds & 531 & - & 19 & - \\
Specialised weaner herds & 3,642 & - & - & 67 \\
Specialised finisher herds & 1,286 & 61 & 39 & 12 \\
Sows, weaners and finishers & 363 & 15 & 8 & - \\
Sows and weaners & 256 & 11 & - & 1 \\
Sows and finishers & 896 & - & 34 & 20 \\
Weaners and finishers & 7,474 & 100 & 100 & 100 \\
\hline Total number of herds & & & & \\
\hline
\end{tabular}

The Danish herd registry (CHR) defines a herd as a group of animals of the same species located together. According to this definition, a famer who owns two neighbouring farms would have two herds. We assumed that LA-MRSA could be eradicated from the herds independently.

\section{Assumptions}

We assumed an annual recurrence of LA-MRSA in $10 \%$ of the herds during the eradication phase. In the post-eradication monitoring period, reintroduction of LA-MRSA was assumed in $5 \%$ of the herds per year. This was a conservative estimate based on Norwegian experience, where the prevalence initially was lower than in Denmark. This recurrence incurred costs for testing, monitoring, depopulation and restocking.

The costs were converted from Danish kroner (DKK) to Euro using the conversion rate of $7.44 \mathrm{DKK} /$ Euro of June $26^{\text {th }}$ 2017. As presented in other Danish societal analyses (Ministry of Finance, 2017) and in a Norwegian study (Hagen et al., 2012), the discount rate used in the analysis was set at 4\%, making the investment in an LA-MRSA-free country comparable with other socioeconomic investments.

\section{Results}

The results of the cost analysis for the LA-MRSA eradication program are given in Table 2 . The costs are divided into planning phase costs, direct net eradication costs during the five-year eradication phase, and derived net costs following eradication, as shown in Fig. 1. The percentage share of the total cost is also presented for each component. 
Table 2. Total estimated cost in millions of eURos (M€) of eradicating la-mRSA in Denmark, divided INTO PLANNING COSTS AND COSTS DURING AND AFTER THE ERADICATION PERIOD

\begin{tabular}{|c|c|c|c|c|c|}
\hline \multirow{3}{*}{ Phase: } & \multicolumn{4}{|c|}{ Costs } & \multirow{2}{*}{$\begin{array}{c}\text { Share } \\
(\%)\end{array}$} \\
\hline & Planning & Eradication & $\begin{array}{c}\text { Post } \\
\text { eradication }\end{array}$ & Total & \\
\hline & $M €$ & $M €$ & M€ & $M €$ & \\
\hline Planning $^{1}$ & 22 & 23 & 17 & 62 & 3 \\
\hline $\begin{array}{l}\text { It was planned that LA-MRSA would be } \\
\text { eradicated from 3,570 farms (some } \\
\text { with multiple herds) during the } \\
\text { eradication period, and a further } 1,700 \\
\text { farms post eradication, with an } \\
\text { estimated cost of } € 13,440 \text { per farm }\end{array}$ & & & & & \\
\hline Monitoring and testing ${ }^{1}$ & 8 & 56 & 45 & 109 & 6 \\
\hline $\begin{array}{l}\text { During the planning phase, all 8,500 } \\
\text { herds were tested at a unit cost of } \\
€ 934 \text {. During the eradication phase, } \\
75,800 \text { herds were expected to be } \\
\text { tested at a cost of } € 934 \text { per herd. Post } \\
\text { eradication, all herds were expected to } \\
\text { be tested once a year, which equates } \\
\text { to } 76,400 \text { herds at the same cost in } \\
\text { real prices. } \\
\text { Administration of the tests was } \\
\text { expected to incur a cost of } € 0.3 \mathrm{M} \\
\text { during the planning phase, } € 1.7 \mathrm{M} \text { in } \\
\text { the eradication period and } € 1.8 \mathrm{M} \text { in } \\
\text { the post-eradication phase } \\
\text { Administration of the tests was } \\
\text { expected to incur a cost of } € 0.3 \mathrm{M} \\
\text { during the planning phase, } € 1.7 \mathrm{M} \text { in } \\
\text { the eradication period and } € 1.8 \mathrm{M} \text { in } \\
\text { the post-eradication phase }\end{array}$ & & & & & \\
\hline Production gains and losses ${ }^{1}$ & & 565 & 29 & 594 & 32 \\
\hline See Appendix 1 & & & & & \\
\hline Cleaning and disinfection $^{1}$ & & 266 & 87 & 353 & 19 \\
\hline
\end{tabular}


million sow pens (including weaner

pens) was expected at a cost of $€ 159$

per sow pen

- It was expected that 4.5 million finisher

pens would be cleaned in the eradication period and 223,000 pens in

the post-eradication period, at a cost of $€ 30.6$ each

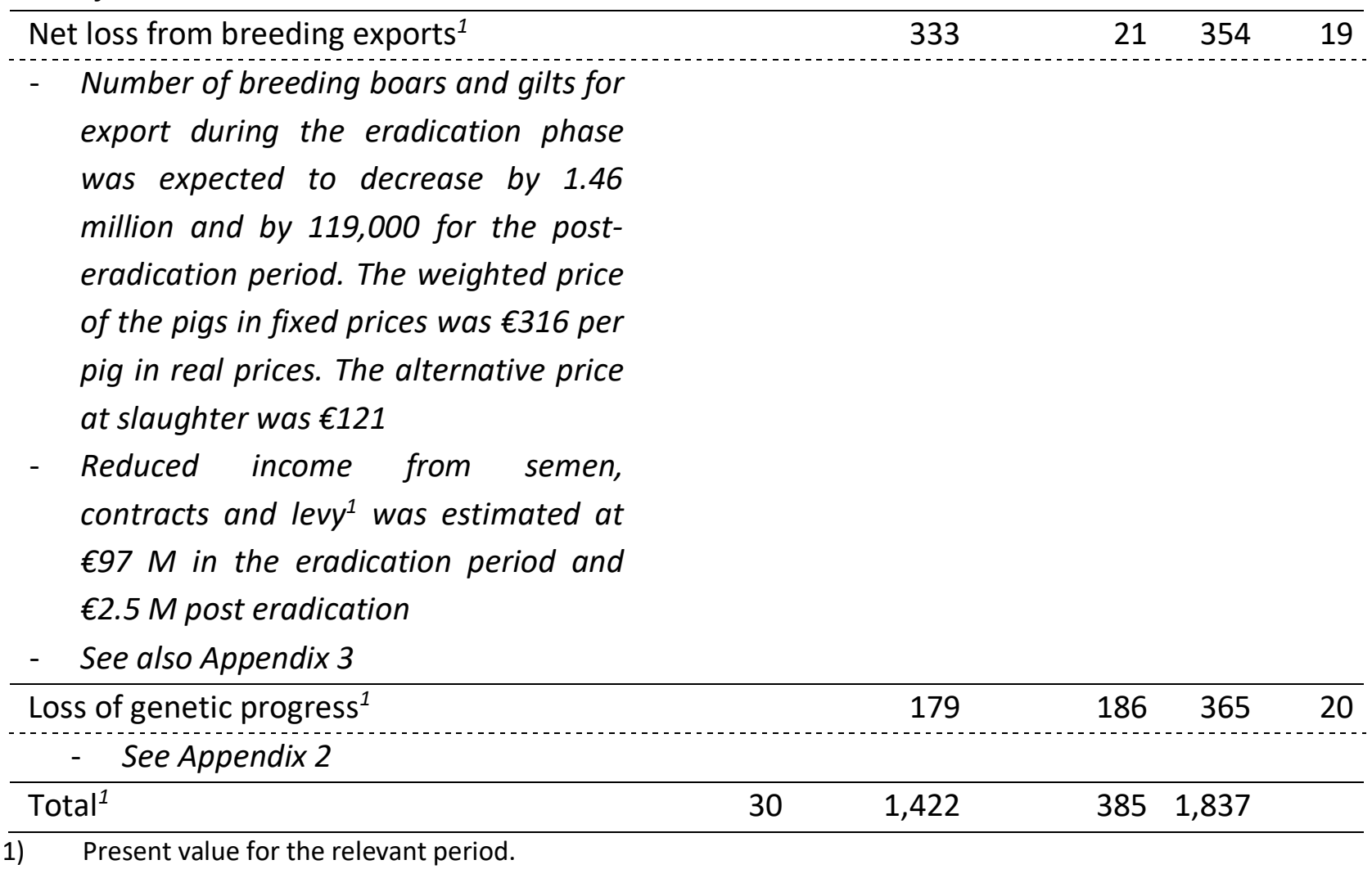

The total cost associated with eradicating LA-MRSA from positive pig herds in Denmark was estimated at $€ 1,837 \mathrm{M}$. This is equivalent to approximately $€ 2,000$ per initially LA-MRSApositive sow, including costs related to weaners and finishers.

\section{Sensitivity analysis}

A sensitivity analysis was performed on what we considered to be the most influential assumptions of the analysis. As we initially chose conservative assumptions, the sensitivity analysis included only those changes resulting in higher costs. The adjustments made included changing the timescale from 15 to 20 years (by adding a longer post-eradication phase); setting the discount rate to $2 \%$ rather than $4 \%$; reducing the future export of breeding animals by $25 \%$ compared to regaining full market share, and a 10\% rather than 5\% annual recurrence of LAMRSA following eradication. The cumulative effects of the changed assumptions were also calculated (Fig. 2). 


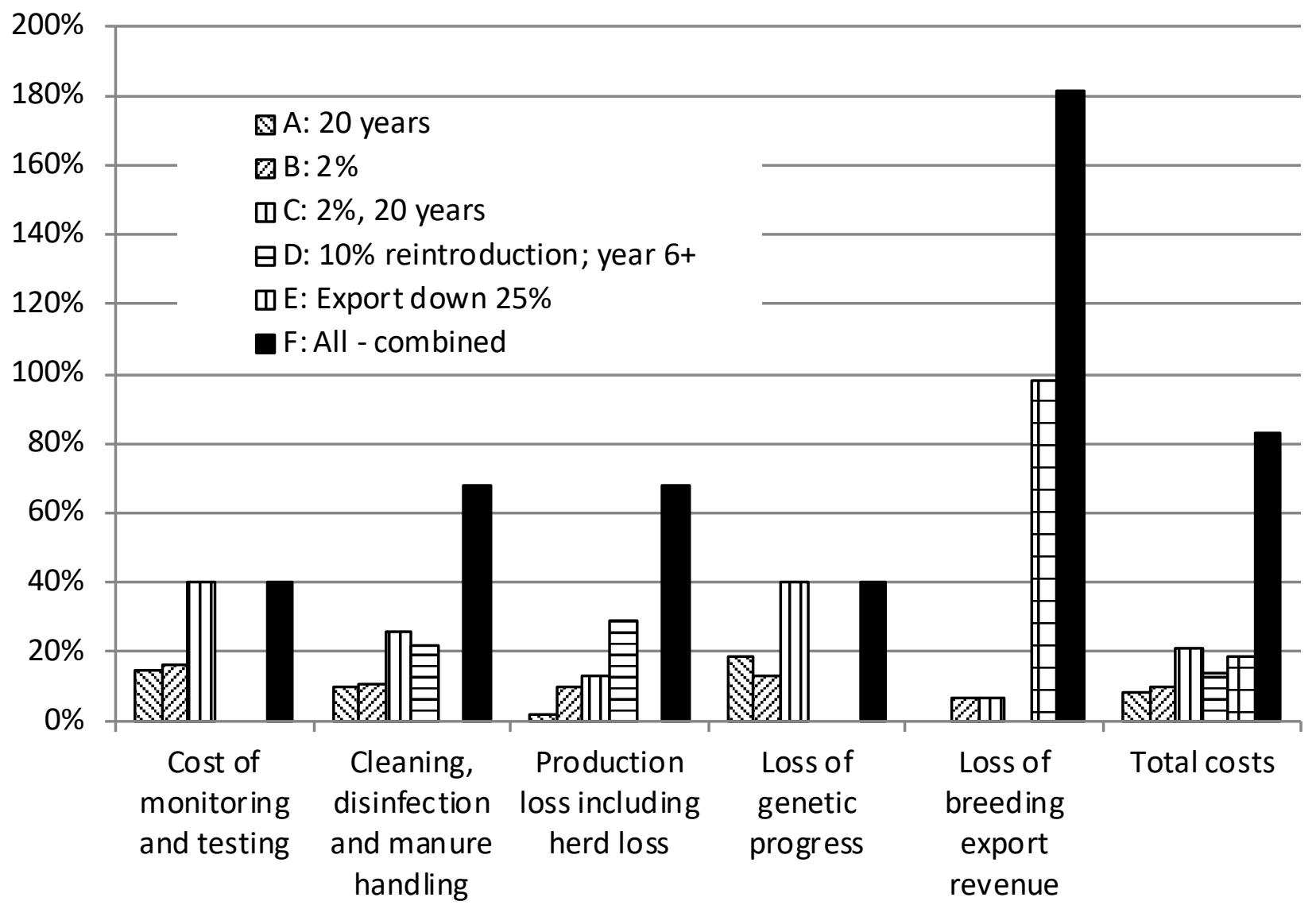

FIG. 2. SENSITIVITY ANALYSIS IN COST ANALYSIS OF ERADICATION IN A HIGH PROPORTION OF HERDS. THE FIGURE SHOWS THE RELATIVE COST INCREASE FOR SIX SCENARIOS COMPARED TO A BASELINE SCENARIO FOR RELEVANT COST COMPONENTS. A: IF TIME HORIZON CONSIDERED WAS 20 YEARS; B: IF DISCOUNT RATE WAS CHOSEN TO BE 2 PERCENT; C: IF BOTH TIME HORIZON AND DISCOUNT RATE WAS ALTERED SIMULTANEOUSLY; D: IF THE REINTRODUCTION RATE WAS ASSUMED TO BE 10 PERCENT AFTER YEAR 6; E: IF THE EX POST ERADICATION EXPORT OF BREEDING ANIMALS AND SEMEN DROPPED BY 25 \%; F: SCENARIOS A THROUGH E SIMULTANEOUSLY.

The total costs were sensitive to a combined change in timescale and discount rate, and to a permanent drop in the export revenue from breeding, as the total costs increased by approximately $20 \%$. If all assumptions were simultaneously changed to the presumed most unfavourable scenarios, the consequence was an $83 \%$ increase in the total costs (Fig. 2). If the recurrence rate was only half of the baseline scenario, i.e. $5 \%$ in the eradication phase and 2.5 percent in the post eradication phase, this would reduce the total costs by $11 \%$. 


\section{Discussion}

This study estimated the direct costs associated with a 15-year LA-MRSA eradication program. We calculated the costs of an eradication program consisting of: a planning phase of one year, an eradication campaign of five years, and nine years testing and re-stocking of farms with $5 \%$ herd reintroduction of LA-MRSA. A conservative approach to prices and consequences was chosen for the assumptions used in the model, and the estimated cost is therefore likely to be too low. However, compared to the potential savings of $€ 106 \mathrm{M}$ in direct costs (the present value of 15 years of savings) due to LA-MRSA in the public health sector (Christensen, 2017), the findings of our study suggest that eradication of LA-MRSA by depopulation of positive farms is not a cost-effective approach under Danish conditions. This is contrary to the conclusions reached in Norway (Norwegian Veterinary Institute, 2016), where the 'trace and destroy' strategy has been deemed cost-effective. Furthermore, a Swedish study (Höjgård et al., 2015) investigated the cost effectiveness of screening all imported animals and culling the LA-MRSA-positive animals, also deeming this to be economically worthwhile. However, the difference seems to be due to a difference in the proportion of positive herds in the initial situation. The theoretical association between the proportion of positive herds and the cost of control/eradication is shown in Fig. 3. This highlights the difference between a scenario with a low proportion of positive herds, such as the Norwegian LA-MRSA situation, and a scenario with a high proportion of positive herds, such as the Danish LA-MRSA situation. The shape of the cost curve and the location of the reported estimates are somewhat subjective.

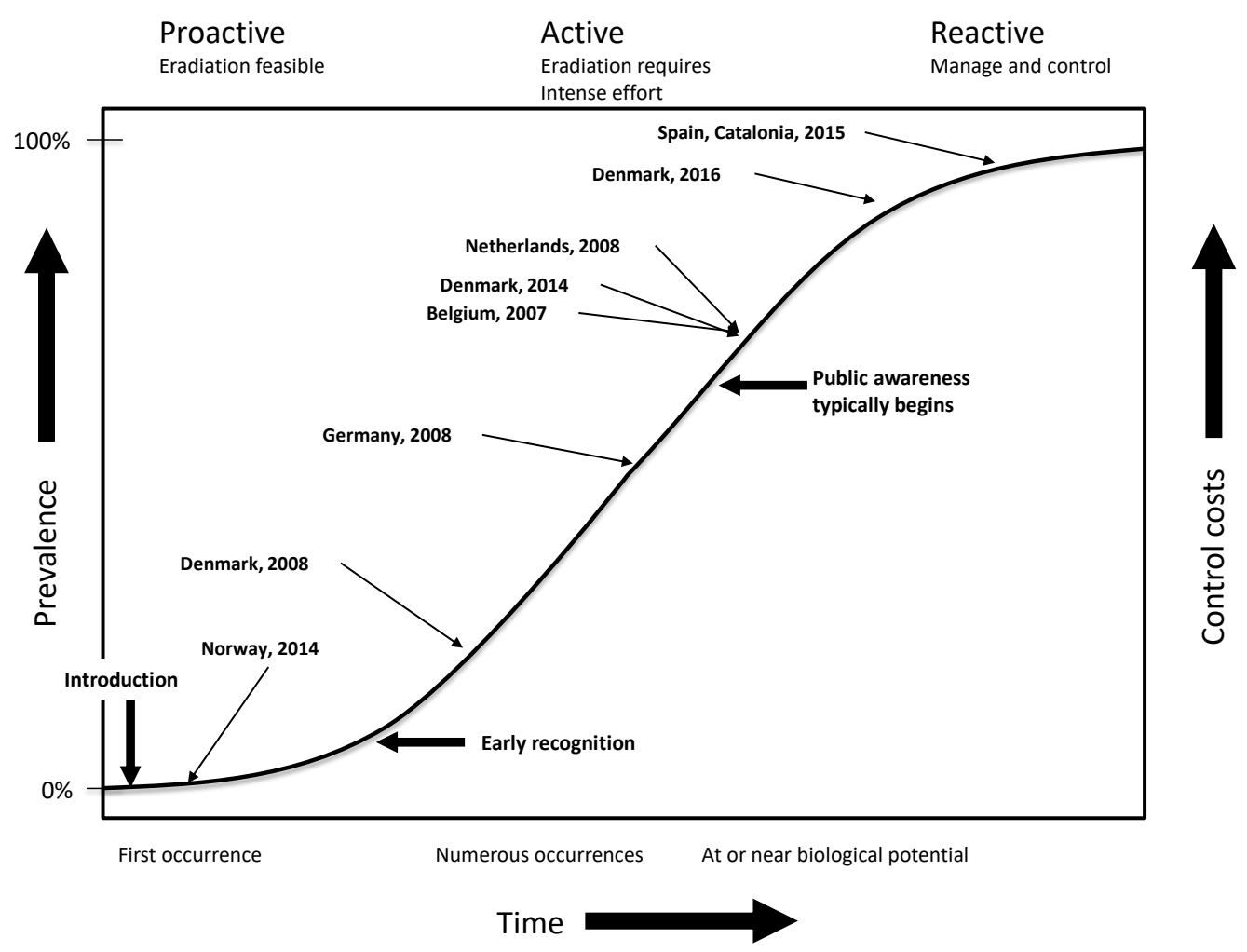


FIG. 3. TYPICAL PHASES OF THE THEORETICAL SPREAD OF BACTERIA WITH THE APPARENT PROPORTION OF LA-MRSA-POSITIVE HERDS IN EUROPEAN COUNTRIES WHERE PIG

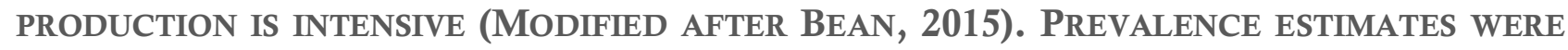
OBTAINED FROM ALT ET AL. (2011); BROENS ET AL. (2011); CROMBÉ ET AL. (2012); REYNAGA ET AL. (2016); DANISH VETERINARY AND FOOD ADMINISTRATION (2017)

Some additional costs associated with eradication could be anticipated but were not quantified. An example would be the losses related to veterinarians being restricted in their planning and practice in order to prevent infecting negative herds. In addition, the anticipated losses associated with restrictions on the trade and transport of pigs were not quantified. The sensitivity analysis was performed for the assumptions we believed to be most uncertain. The most crucial assumption considered was the reintroduction rate, which we assumed to be comparable to those seen for endemic pig diseases. However, we have no real evidence to support what the post-eradication reintroduction rate of LA-MRSA would be in Denmark. The derived societal costs should also be investigated further to estimate the total costs of eradication of LA-MRSA in the Danish pig population.

It could be argued that a potentially higher price for pig meat free from LA-MRSA should be considered in the cost analysis. The assumption of no price premium for LA-MRSA-free pig meat, however, seems realistic in the current situation where all major pig-producing countries have cases of LA-MRSA, and it is widely assumed that infected meat does not pose a health hazard. However, this may change in the future.

\section{Conclusion}

The costs of eradicating LA-MRSA from the pig population are considerable when the proportion of positive herds is as high as in Denmark. Associated benefits from improved human and pig health, and reduced costs in the hospital sector are much lower than the cost of eradication, which is why this option does not appear to be cost-effective in the Danish context.

The conservative approach pursued here included a lower threshold of the expected costs, and the sensitivity analysis, which included plausible assumptions, showed a potential increase of $83 \%$ in the total cost - from $€ 1.8$ billion to $€ 3.4$ billion. In the baseline scenario, $60 \%$ of the costs were due to eradication and production losses emerging from the eradication program, while $40 \%$ were due to losses in export and genetic progress. For countries predominantly importing their genetic materials, the total cost might be reduced by excluding the latter components. 


\section{Acknowledgements and source of funding}

The study was funded by the Danish Ministry of Environment and Food as part of a detailed expert statement about LA-MRSA handling in Denmark. The study was supported by a grant from the Ministry of Environment and Food of Denmark through The Danish Agrifish Agency [Grant number 33010-NIFA-14-612].

\section{Conflicts of interest}

Some input was received from the Danish Agricultural and Food Council, which has an interest in an upward bias in the results. To counter this, the input was validated against statistics that had been published in an unrelated context. Furthermore, a conservative cost strategy was pursued and supplemented with sensitivity analyses and an evaluation of the uncertainty associated with the results. Some input (e.g. surveillance program costs and the cost of testing) was received from the Danish Ministry of Environment and Food, who are also involved in LA-MRSA strategies.

\section{References}

Alt, K., Fetsch, A., Schroeter, A., Guerra, B., Hammerl, J.A., Hertwig, S., Senkov, N., Geinets, A., Mueller-Graf, C., Braeunig, J., Kaesbohrer, A., Appel, B., Hensel, A., Tenhagen, B., 2011. Factors associated with the occurrence of MRSA CC398 in herds of fattening pigs in Germany. BMC Vet. Res. 7, 69. https://doi:10.1186/1746-6148-7-69.

Armand-Lefevre, L., Ruimy, R., Andremont, A., 2005. Clonal Comparison of Staphylococcus aureus Isolates from Healthy Pig Farmers, Human Controls, and Pigs. Emerg. Infec. Dis. 11, 711-714. https://doi:10.3201/eid1105.040866.

Asheim, L.J., Hopp, P., Grøneng, G.M., Nafstad, O., Hegrenes, A., Vatn, S., 2017. A financial cost-benefit analysis of eradicating virulent footrot. Prev. Vet. Med. 146, 86-93, http://dx.doi.org/10.1016/j.prevetmed.2017.07.017.

Bean, T., 2015. Lag times in plant invasions: here today, everywhere tomorrow. http://ucanr.edu/blogs/blogcore/postdetail.cfm?postnum=18530 (accessed 03 October 2017).

Broens, E. M., Graat, E. A. M., Van Der Wolf, P. J., Van De Giessen, A. W., \& De Jong, M. C. M., 2011. Prevalence and risk factor analysis of livestock associated MRSA-positive herds in The Netherlands. Prev. Vet. Med. 102, 41-49.

https://doi.org/10.1016/j.prevetmed.2011.06.005.

Christensen, T., 2017. Bilagsrapport om sundhedsøkonomiske analyser af forekomst af husdyrMRSA i svin, 39 p., IFRO Commissioned report, No. 2017/10a. University of Copenhagen. 
https://curis.ku.dk/ws/files/182262547/IFRO_Udredning_2017_10a.pdf (accessed 7 January 2018).

Crombé, F., Willems, G., Dispas, M., Hallin, M., Denis, O., Suetens, C., Gordts, B., Struelens, M., Butaye, P., 2012. Prevalence and antimicrobial susceptibility of MethicillinResistant Staphylococcus aureus among pigs in Belgium. Microb. Drug Resist. 18, 2. https://dx.doi.org/10.1089/mdr.2011.0138.

Danish Veterinary and Food Administration, 2017. Results from screening of Livestock Associated MRSA in pigs in 2016 [in Danish]. Danish Veterinary and Food Administration (Ed.).

https://www.foedevarestyrelsen.dk/Nyheder/Aktuelt/Documents/MRSA\%20ekspertgruppe \%20-\%20resultatene $\% 20$ forekomst $\% 20$ af $\% 20$ husdyr-MRSA $\% 201 \% 20$ svin $\% 202016$.pdf. ( accessed 03 October 2017).

DANMAP, 2015. DANMAP 2015 - Use of antimicrobial agents and occurrence of antimicrobial resistance in bacteria from food animals, food and humans in Denmark. In: Høg, B.B., Korsgaard, H. (Eds.) Statens Serum Institut, National Veterinary Institute, Technical University of Denmark, National Food Institute, Technical University of Denmark. http://www.danmap.org/ /media/Projekt\%20sites/Danmap/DANMAP\%20reports/DAN MAP\%20\%202015/DANMAP\%202015.ashx (accessed 03 October 2017).

Grøntvedt, C.A., Elstrøm, P., Stegger, M., Skov, R.L., Skytt Andersen, P., Larssen, K.W., Urdahl, A.M., Angen, Ø., Larsen, J., Åmdal, S., Løtvedt, S.M., Sunde, M., Bjørnholt, J.V., 2016. Methicillin-Resistant Staphylococcus aureus CC398 in Humans and Pigs in Norway: A "One Health" Perspective on Introduction and Transmission. Clin. Infect. Dis. 63, 1431-1438. https://doi:10.1093/cid/ciw552.

Hagen, K.P., Berntsen, S., Bye, B., Hultkrantz, L., Nyborg, K., Pedersen, K.R., Sandsmark, M., Volden, G.H., Åvitsland, G., 2012. Samfunnsøkonomiske analyser. In: Departementenes servicesenter Informasjonsforvaltning (Ed.), Norges Offentlige Utredninger.

https://www.regjeringen.no/no/dokumenter/nou-2012-16/id700821/sec1 (accessed 03 October 2017).

Houe, H., 2003. Economic impact of BVDV infection in dairies. Biologicals 31, 137-143. http://dx.doi.org/10.1016/S1045-1056(03)00030-7.

Huirne, R.B.M., Dijkhuizen, A.A., 1997. Basic methods of economic analysis. In: Morris, A.A.D.a.R.S. (Ed.), Animal Health Economics. Principles and Applications. University of Sydney, Sydney, pp. 25-39. 
Höjgård, S., Aspevall, O., Bengtsson, B., Hæggman, S., Lindberg, M., Mieziewska, K., Nilsson, S., Ericsson Unnerstad, H., Viske, D., Wahlström, H., 2015. Preventing Introduction of Livestock Associated MRSA in a Pig Population - Benefits, Costs, and Knowledge Gaps from the Swedish Perspective. PLOS ONE 10, https://dx.doi.org/10.1371/journal.pone.0122875.

Jespersen, C. 2008: Genetics, Study notes. Chapter 8: Selection Response. http://www.ihh.kvl.dk/htm/kc/popgen/genetics/8/8/tsld001.htm (accessed 05 September 2017).

Kristensen, C.S., Christiansen, M.G., 2013. Estimat for omkostninger ved PRRS i Danmark. Meddelelse. Videncenter for Svineproduktion. http://svineproduktion.dk/-/media/PDF--Publikationer/Meddelelser-2013/Meddelelse 985 ESTIMAT-FOR-OMKOSTNINGERVED-PRRS-I-

DANMARK.ashx?la=da\&hash=E5916F35D48D9546A687113EE93ABB11BCC6288B (accessed 18 August 2017).

Larsen, J., Petersen, A., Sørum, M., Stegger, M., van Alphen, L., Valentiner-Branth, P., Knudsen, L.K., Larsen, L.S., Feingold, B., Price, L.B., Andersen, P.S., Larsen, A.R., Skov, R., 2015. Meticillin-resistant Staphylococcus aureusCC398 is an increasing cause of disease in people with no livestock contact in Denmark, 1999 to 2011. Euro Surveill. 20 (37). http://doi.org/10.2807/1560-7917.ES.2015.20.37.30021.

Ministry of Environment and Food of Denmark, 2017. The Central Husbandry Register (CHR). In: Danish Veterinary and Food Administration (Ed.).

https://www.foedevarestyrelsen.dk/english/Animal/AnimalHealth/Central Husbandry Reg ister/Pages/default.aspx (accessed 03 October 2017).

Ministry of Finance, 2017. Vejledning i samfundsøkonomiske konsekvensvurderinger. https://www.fm.dk/publikationer/2017/vejledning-i-samfundsoekonomiskekonsekvensvurderinger (accessed 03 October 2017).

Nathues, H., Alarcon, P., Rushton, J., Jolie, R., Fiebig, K., Jimenez, M., Geurts, V., Nathues, C., 2017. Cost of porcine reproductive and respiratory syndrome virus at individual farm level - An economic disease model. Prev. Vet. Med. 142, 16-29. https://doi.org/10.1016/j.prevetmed.2017.04.006.

Norwegian Veterinary Institute, 2016, Spredningsmodell og samfunnsøkonomisk analyse av tiltak mot LA-MRSA. Report No. 13. https://www.vetinst.no/rapporter-ogpublikasjoner/rapporter/2016/spredningsmodell-og-samfunnsokonomisk-analyse-av-tiltakmot-la-mrsa (accessed 28 February 2018). 
Oldenbroek, K., Waaij, L.v.d., 2014. Animal Breeding and genetics for BSc students. In: Kennisnet, G. (Ed.), http://www.wur.nl/upload_mm/d/b/b/614bcc19-036f-434e-9d40609364ab26da_Textbook\%20Animal\%20Breeding\%20and\%20Genetics-v1720151122_1057.pdf (accessed 03 October 2017).

Pig Research Centre, 2014. Danavl årsprofil. http://svineproduktion.dk/Services//media/383B3981834F4351A8290AB83BD5C766.ashx (accessed 03 October 2017).

Pig Research Centre, 2016. Danavl årsprofil. http://svineproduktion.dk/Services//media/07FA125A969C47FBB27973E6CA15619A.ashx (accessed 03 October 2017).

Rauw, W.M., 2008. Resource allocation theory applied to farm animal production. CAB International, Oxfordshire.

Reynaga, E., Navarro, M., Vilamala, A., Roure, P., Quintana, M., Garcia-Nunez, M., Figueras, R., Torres, C., Lucchetti, G., Sabria, M., 2016. Prevalence of colonization by methicillin-resistant Staphylococcus aureus ST398 in pigs and pig farm workers in an area of Catalonia, Spain. BMC Infect. Dis. 16, 716. http://dx.doi.org/10.1186/s12879-016-2050-9.

Rushton, J., 2009. The economics of animal health and production. CABI Wallingford. Thomann, B., Tschopp, A., Magouras, I., Meylan, M., Schüpbach-Regula, G., Häsler, B., 2017. Economic evaluation of the eradication program for bovine viral diarrhea in the Swiss dairy sector. Prev. Vet. Med. 145, 1-6. http://dx.doi.org/10.1016/j.prevetmed.2017.05.020.

Voss, A., Loeffen, F., Bakker, J., Klassen, C., Wulf, M., 2005. Methicillin-resistant Staphylococcus aureus in Pig Farming. Emerg. Infect. Dis. 11, 1965-1966 doi: https://dx.doi.org/10.3201/eid1112.050428.

\section{Appendix 1}

\section{Production losses}

The annual numbers of produced pigs of different age groups (Table A1) were used to calculate the production loss.

TABLE A1. NUMBER OF PIGLETS, WEANERS AND SLAUGHTERED FINISHER PIGS PRODUCED IN DENMARK DURING 2016, USED TO CALCULATE THE EXPECTED OUTPUT LOSS

\begin{tabular}{ll}
\hline Type of pig & Thousand pigs \\
\hline Piglets produced & 33,100 \\
Weaners produced & 31,400 \\
Finishers slaughtered & 17,800 \\
\hline
\end{tabular}


The loss of expected output was calculated separately for specialised and integrated herds (Table 1), because the value of production loss was dependent on the duration of ceased production during eradication. Losses would be higher for an integrated herd in which the finisher section was emptied and cleaned before restocking. Within 12 weeks of emptying the farm, it was expected that the cleaning, disinfection and handling of manure would be complete. The period of operational losses was also dependent on the herd structure (Table A2).

TABLE A2. PRODUCTION LOSS (IN WEEKS) FOR DIFFERENT PRODUCTION HERD TYPES (WITH OFF-SITE GESTATING GILTS) DURING EACH STAGE OF THE ERADICATION PROGRAM

\begin{tabular}{l|llll}
\hline $\begin{array}{l}\text { Herd type / Eradication } \\
\text { program stage }\end{array}$ & Depopulation & Empty & Restocking & $\begin{array}{l}\text { Operational } \\
\text { losses }\end{array}$ \\
\hline Integrated, piglets & 20 & 20 & 6 & 26 \\
Integrated, weaners & 8 & 18 & 8 & 26 \\
Integrated, finisher pigs & 13 & 26 & 13 & 39 \\
Specialised, piglets & 20 & 14 & 6 & 20 \\
Specialised, weaners & 8 & 12 & 8 & 20 \\
Specialised, finisher pigs & 13 & 12 & 13 & 25 \\
\hline
\end{tabular}

The eradication process was not expected to be $100 \%$ successful due to reintroductions or unsuccessful eradication in the multiplier herds, resulting in subsequent production losses. The multiplier herds have contracts with the breeding company to multiply genes via high quality gilts to the production herds. Each multiplier herd subject to reintroduction was expected to result in a prolonged production loss at two production herds due to a failure in supplying gilts. If eradication was planned so that the supply of gilts matched the demand, then it would be necessary for a multiplier herd subject to reintroduction to suspend gilt supply to their customers.

The assumed price of pig meat during an eradication phase influenced the production loss, with higher losses associated with higher prices and vice versa. The assumed price was chosen to cover costs exactly, which included all resources such as owner remuneration and return on equity. This break-even price would be predicted under perfect competition conditions including identical farms, and free entry and exit. Gross margins adjusted according to the description in the Materials and Method section and the break-even pig price are presented in Table A3. 
TABLE A3. ADJUSTED GROSS MARGINS, IN EUROS ( $($ ), FOR LABOUR AND ENERGY. ESTIMATES USED FOR THE COST ANALYSIS FOR DIFFERENT TYPES OF PIGS

\begin{tabular}{ll}
\cline { 2 - 2 } Adjusted $^{1}$ gross margins & $\begin{array}{l}\text { Euros } \\
(€)\end{array}$ \\
\hline Gross margin per piglet produced & 14.66 \\
Gross margin per weaner pig & 4.98 \\
Gross margin per finisher pig & 16.68 \\
\hline
\end{tabular}

${ }^{1}$ Gross margin including share of energy and labour costs.

The duration of the production loss, total production of LA-MRSA-positive pigs during a year per herd type, loss per unit produced, and total operational losses are presented in Table A4.

TABLE A4. OPERATIONAL LOSSES IN DIFFERENT HERD TYPES GIVEN THE DURATION OF ERADICATION, THE PRODUCTION, AND THE LOSS PER UNIT PRODUCED

\begin{tabular}{lllll}
\hline Herd type, section & $\begin{array}{l}\text { Loss } \\
\text { (weeks) }\end{array}$ & $\begin{array}{l}\text { Production } \\
\text { (million pigs) }\end{array}$ & $\begin{array}{l}\text { Operational loss } \\
(€ \text { per unit) }\end{array}$ & $\begin{array}{l}\text { Total operational } \\
\text { loss }(€ \mathrm{M})\end{array}$ \\
\hline Integrated, piglets & 26 & 26.3 & 25.2 & 185 \\
Integrated, weaners & 26 & 15.9 & 15.3 & 38 \\
Integrated, finisher pigs & 39 & 6.4 & 6.0 & 76 \\
Specialised, piglets & 20 & 7.9 & 14.7 & 45 \\
$\begin{array}{l}\text { Specialised, weaners } \\
\text { Specialised, finisher pigs }\end{array}$ & 20 & 16.8 & 5.0 & 32 \\
\hline $\begin{array}{l}\text { Total nominal } \\
\text { operational loss }\end{array}$ & 12.2 & 16.7 & 98 \\
\hline
\end{tabular}

The estimated time span of the production losses was five years because the supply of LAMRSA-negative gilts was expected to be limited. This supply was expected to be higher towards the end of the eradication program because the multiplier herds were expected to be free from LA-MRSA. Depopulation of a high proportion of the farms could be considered an opportunity to improve the general health of the pig population by reducing the prevalence of (or even eradicating) certain diseases such as PRRS, Porcine Pleuropneumonia and Enzootic Pneumonia. PRRS has been associated with an annual loss of $€ 17 \mathrm{M}$ (recalculated for 2016 prices; Kristensen \& Christiansen, 2013), and it was assumed that Actinobacillus pleuropneumoniae and Enzootic Pneumonia together would incur losses for Danish pig producers of the same magnitude, although Nathues et al., (2017) estimated higher losses for these diseases. 


\section{Appendix 2}

\section{Loss of breeding progress}

The genetic progress was calculated for one of the breeds, and we assumed that it was similar for the two other breeds. With 2,000 breeding sows, the demand for testable gilts was about 4,600 gilts per year, with a baseline replacement rate of $70 \%$ per litter (approximately $150 \%$ per year). The demand for boars was 100 per year for each breed.

It was assumed that each sow would produce ten female and ten male piglets per year, totalling a potential 20,000 gilts per year for each breed, and yielding a selection intensity of $23 \%$ $(4,600 / 20,000)$. The boar selection was $0.5 \%(100 / 20,000)$. During the eradication program, the gilt selection was $0 \%$, as all gilts were expected to be utilised, and the boar selection was $3.57 \%$ (100 used boars/(20,000 boars produced*(1-0.86 (eradicated share of nucleus herds)))). In Oldenbroek and Waaij (2014), the baseline selection for boars with $0.5 \%$ selection yielded a selection intensity ( $i$ ) of 2.89 , and the $23 \%$ gilt baseline selection gave an intensity $(i)$ of 1.32 . The eradication selection for boars with 3.57\% selection yielded an intensity (i) of 2.20 (by linear interpolation). The average selection intensity for sows and boars before eradication was 2.106 . The average selection intensity during the eradication program was calculated at 1.10 , ( 2.20 before +0 after $) / 2$.

The change in breeding progress was found using the ratio of breeding progress prior to and during eradication $(1,100 / 2,106)$, leading to $52 \%$ of the breeding progress being sustained and consequently $48 \%$ of the breeding progress being lost during the eradication period. This was worth $€ 1.7 * 47.8 \%=€ 0.81$ per year for each pig.

It was expected to take approximately 1.64 years before the production of gilts would return to the pre-eradication level, resulting in a selection intensity and breeding progress similar to that of pre-eradication levels. This meant that the loss sustained due to suspended genetic progress during the eradication program was $€ 0.81 * 1.64$ year $=€ 1.33$ per pig.

If a caesarean strategy was not pursued, the full loss of genetic progress could be calculated as the annual production of 31.4 million pigs with a loss of $€ 1.33$ per pig, or $€ 42 \mathrm{M}$ per year. The breeding progress was a yearly loss, with a present value calculated at $€ 425 \mathrm{M}$ for years six to 15 .

The cost of caesarean sections as a means to reduce breeding progress loss was approximated for the procedure outlined below. Each week, a number of the best sows should be transported to a caesarean facility, and the piglets subsequently bottle fed at an LA-MRSA-negative nursery. This should happen at a pace that could supply the farm with a sufficient number of useful gilts at the age of 35 weeks. After 21 weeks of performing caesareans, the number would be lowered to match the need for replacement gilts. Subsequently, the sow replacement rate was expected to be higher than usual due to the poorer health of the nursery pigs as a result of bottle feeding. 
The correlation between the embryo genetic ranking and the genetic ranking at testing age was assumed to be 0.5 . High gilt mortality caused by poor health led to the additional loss of genetic value. The cost of caesarean sections was estimated at $€ 9,400$ per litter, resulting in the total cost of the program being approximately $€ 79 \mathrm{M}$. Use of caesareans was expected to reduce the loss of genetic progress by $€ 142 \mathrm{M}$. With the cost of the program at $€ 79 \mathrm{M}$, the savings would be $€ 62 \mathrm{M}$, yielding a total estimated loss of breeding progress of $€ 365 \mathrm{M}$.

Danish pig production was also expected to be based primarily on Danavl gilts due to the availability of only a limited set of LA-MRSA-negative foreign gilts. It was assumed that 50,000 Norwegian gilts could be imported into Denmark annually.

\section{Appendix 3}

\section{Loss of export revenue for gilts, boars and semen}

Exported breeding animals have higher revenue compared to slaughter pigs if there is a foreign demand for Danish gilts. There was an expected reduction in the competitiveness of the Danavl breeding company following the eradication program because competitors could retain full breeding progress compared to the reduced progress of Danavl during the eradication period. Nonetheless, exports of gilts, boars and semen were expected to recover to full value seven years after the eradication program was initiated.

The expected share of export market lost during the eradication program was estimated based on the principle that gilts testing positive for LA-MRSA could be exported until all nucleus and multiplier herds had undergone eradication (Table A5). It was expected that export value would revert to the baseline level by 2025 .

TABLE A5. SHARE OF THE EXPORT MARKET FOR BREEDING ANIMALS AND SEMEN EXPECTED TO BE LOST DUE TO AN ERADICATION STRATEGY. AN EXPORT LOSS IS ALSO EXPECTED AFTER THE ERADICATION PHASE DUE TO COMPETITION.

\begin{tabular}{|c|c|c|c|c|c|c|}
\hline & $\begin{array}{l}2019 \\
\% \text { lost }\end{array}$ & $\begin{array}{l}2020 \\
\% \text { lost }\end{array}$ & $\begin{array}{l}2021 \\
\% \text { lost }\end{array}$ & $\begin{array}{l}2022 \\
\% \text { lost }\end{array}$ & $\begin{array}{l}2023 \\
\% \text { lost }\end{array}$ & $\begin{array}{l}2024 \\
\% \text { lost }\end{array}$ \\
\hline Purebred gilts & 5 & 100 & 100 & 75 & 50 & 25 \\
\hline Crossbred gilts & 5 & 50 & 100 & 100 & 50 & 25 \\
\hline $\begin{array}{l}\text { Danish Landrace and Yorkshire } \\
\text { boars }\end{array}$ & 5 & 50 & 40 & 25 & 10 & 0 \\
\hline Duroc boars & 5 & 50 & 40 & 25 & 10 & 0 \\
\hline Duroc semen & 5 & 50 & 40 & 25 & 10 & 0 \\
\hline Foreign internal breed & 0 & 0 & 0 & 0 & 0 & 0 \\
\hline Share of breed-tax lost (export) & 5 & 90 & 90 & 75 & 40 & 15 \\
\hline
\end{tabular}

When gilts and boars were not exported, the animals were expected to be slaughtered. 